\title{
IMPLEMENTASI KETERBUKAAN INFORMASI PUBLIK PADA KANTOR WILAYAH KEMENTERIAN AGAMA PROVINSI KALIMANTAN TENGAH
}

\author{
Implementation Of Public Information Disclosure On The Regional Office \\ Of Provincial Religious Ministry Of Central Kalimantan
}

\section{Hasan Basri* Mambang}

Universitas Muhammadiyah Palangkaraya, Palangka Raya, Central Kalimantan, Indonesia

email:

mambang@umpalangkaraya.ac.id

Kata Kunci:
Implementasi
Kebijakan
Keterbukaan
Informasi
Publik

Keywords:
Implementation
Policy
Openness
Information
Public

Accepted

June 2019

\section{Published}

Oktober 2019

\begin{abstract}
Abstrak
Penelitian ini bertujuan untuk mengekplore implementasi keterbukaan informasi publik dinilai masih mengalami berbagai kendala. Hal itu setidaknya ditunjukkan dengan hasil penilaian Komisi Informasi Provinsi Kalimantan Tengah seperti tercantum dalam SK Komisi Informasi Provinsi Kalimantan Tengah Nomor: 048/KEP/KI Kalteng/20I8 tanggal 12 Oktober 2018, di mana Kantor Wilayah Kementerian Agama Provinsi Kalimantan Tengah mendapatkan nilai 39,3.
\end{abstract}

Penelitian dilakukan menggunakan perspektif kualitatif dengan metode studi kasus. Pengumpulan data dilakukan dengan metode wawancara dan studi dokumen. Penelitian dilakukan pada Kantor Wilayah Kementerian Agama Provinsi Kalimantan Tengah.

Hasil penelitian menunjukkan pada implementasi keterbukaan informasi publik pada Kantor Wilayah Kementerian Agama Provinsi Kalimantan Tengah telah dijalankan. Beberapa layanan informasi publik sebagaimana diatur dalam perundang-undangan yang berlaku, telah dipublikasikan. Namun, masih terdapat kendala yang dihadapi dalam implementasi tersebut sehingga membuat sejumlah informasi publik yang belum dipublikasikan. Kendala tersebut berkaitan dengan isi kebijakan dan lingkungan implementasinya.

\begin{abstract}
This research aims to expand the implementation of public information disclosure assessed still experiencing various obstacles. It was at least indicated by the assessment of the central Kalimantan Provincial Information Committee as stated in the Central Kalimantan Provincial Information Commission DECREE number: 048/KEP/KI Kalteng/2018 dated October 12, 2018, where the regional office of the Ministry of Religious Affairs in central Kalimantan was given a value of 39.3 .

Research is conducted using a qualitative perspective with a case study method. Data collection is done by interview method and document study. The research was conducted at the Regional office of the provincial religious Ministry of Central Kalimantan.

The results of the study showed that the implementation of public information disclosure in the regional office of the provincial religious Ministry of central Kalimantan was executed. Some public information services as regulated in the applicable legislation have been published. However, there are still obstacles encountered in the implementation to make some public information that has not been published. These constraints relate to the contents of the policy and its implementation environment.
\end{abstract}

\section{PENDAHULUAN}

Badan publik yang diatur melalui Undang-Undang itu menurut Peraturan Pemerintah Republik Indonesia Nomor 6I Tahun 2010 tentang Pelaksanaan UndangUndang Nomor 14 Tahun 2008 Tentang Keterbukaan Informasi Publik adalah lembaga Negara dan lembaga atau organisasi non pemerintah yang sebagian atau seluruh dananya bersumber dari dana publik, baik Anggaran Pendapatan dan Belanja Negara/Anggaran Pendapatan dan Belanja Daerah, sumbangan masyarakat, maupun sumber luar negeri. Sebagai sebuah lembaga yang anggaran dananya berasal dari Anggaran 
Pendapatan dan Belanja Negara sebagaimana tercantum dalam Peraturan Pemerintah tersebut, Kementerian Agama beserta seluruh satuan dan unit kerja di jajarannya wajib menjamin keterbukaan informasi publik.

Peraturan Komisi Informasi Nomor I Tahun 2010 tentang Standar Layanan Informasi Publik menyebutkan sejumlah hal yang harus dipenuhi oleh badan publik dalam kewajibannya menjalankan keterbukaan informasi. Badan publik memiliki kewajiban mengumumkan informasi secara berkala, secara serta merta, serta informasi yang wajib tersedia setiap saat.

Pengembangan sistem informasi dan dokumentasi dalam rangka pengelolaan informasi publik pada Kantor Wilayah Kementerian Agama Provinsi Kalimantan Tengah diwujudkan melalui keberadaan media internal yang terdiri dari website, majalah dinas, serta akun media sosial dalam berbagai platformnya. Ketiganya dipandang sesuai dengan perkembangan teknologi informasi dan komunikasi saat ini.

Media internal yang dikelola oleh Subbagian Informasi dan Humas tersebut adalah website yang beralamat di https://kalteng.kemenag.go.id dan Majalah Cermien yang merupakan majalah dinas terbitan tiga bulanan. Sedangkan akun media sosial yang dikelola adalah Facebook, Instagram, dan Twitter. Bagi Kantor Wilayah Kementerian Agama Provinsi KalimantanTengah, keberadaan media tersebut menjadi bagian dari kampanye informasi dan pemenuhan perintah Undang-Undang yang mewajibkan adanya keterbukaan informasi publik.

Kantor Wilayah Kementerian Agama Provinsi Kalimantan Tengah berupaya mendorong agar pengelolaan website, majalah, dan akun media sosial semakin meningkat dan mencapai khalayak dalam jumlah dan variasi yang luas. Berdasarkan arsip Subbag Informasi dan Humas menunjukkan bahwa terdapat surat Kepala Kantor Wilayah Kementerian Agama Provinsi Kalimantan Tengah yang ditujukan kepada Kantor Kementerian Agama Kabupaten/Kota se-
Kalimantan Tengah agar diambil langkah untuk melakukan optimalisasi fungsi kehumasan dan keterbukaan informasi publik, melalui peningkatan pemberitaan website, majalah, dan pengelolaan akun media sosial.

Penelitian awal menunjukkan bahwa implementasi keterbukaan informasi publik pada Kantor Wilayah Kementerian Agama Provinsi Kalimantan Tengah perlu ditingkatkan. Hal itu didasarkan pada hasil penilaian Komisi Informasi Provinsi Kalimantan Tengah seperti tercantum dalam SK Komisi Informasi Provinsi Kalimantan Tengah Nomor: 048/KEP/KI Kalteng/2018 tanggal 12 Oktober 2018. Kantor Wilayah Kementerian Agama Provinsi Kalimantan Tengah mendapatkan nilai 39,3, sebuah nilai yang terpaut cukup jauh dengan instansi vertikal lainnya yang mendapatkan penilaian serupa. Artinya, implementasi keterbukaan informasi publik tersebut memerlukan pembenahan dan perbaikan demi memenuhi standar layanan yang telah ditetapkan oleh Komisi Informasi.

Saat Komisi Informasi Provinsi Kalimantan Tengah melakukan verifikasi implementasi keterbukaan informasi publik pada Subbagian Informasi dan Humas Kantor Wilayah Kementerian Agama Provinsi Kalimantan Tengah, ditemukan bahwa terdapat beberapa hal yang perlu diperbaiki dalam implementasi tersebut. Di antaranya keharusan adanya informasi tentang anggaran pada Kantor Wilayah Kementerian Agama Provinsi Kalimantan Tengah, rencana program yang akan dilaksanakan dalam satu tahun, realisasi program berjalan, serta neraca anggaran dan aset barang milik negara. Diperlukan pula perbaikan pada sisi pejabat pengelola informasi dan dokumentasi (PPID) dalam hal pemenuhan anggaran operasional dan ruang sekretariat agar bisa menjalankan tugas pemenuhan informasi kepada khalayak.

Oleh karena itu, menjadi sangat menarik untuk melakukan kajian atas layanan informasi publik serta beragam hal yang menjadi faktor penghambatnya atas tata kelola keterbukaan informasi publik pada Kantor 
Wilayah Kementerian Agama Provinsi Kalimantan Tengah. Hal itu penting untuk melihat sejauh mana layanan informasi yang diberikan jika ditilik dari sisi kajian akademik, yang diharapkan bisa menjadi masukan bagi Kantor Wilayah Kementerian Agama Provinsi Kalimantan Tengah.

\section{METODOLOGI}

Penelitian ini adalah penelitian dalam perspektif kualitatif dengan menggunakan metode studi kasus untuk membuat deskripsi secara sistematis, faktual dan akurat yang memberikan gambaran dan analisa tentang implementasi keterbukaan informasi publik, meliputi layanan informasi yang diberikan dan kendala yang dihadapi pada Kantor Wilayah Kementerian Agama Provinsi Kalimantan Tengah.

\section{HASIL DAN PEMBAHASAN}

Keterbukaan informasi publik merupakan sebuah hal yang harus dilakukan oleh setiap badan publik termasuk Kantor Wilayah Kementerian Agama Provinsi Kalimantan Tengah. Keterbukaan informasi ini diharapkan menjadi tonggak untuk mengakhiri budaya ketertutupan dan kerahasiaan. Kerahasiaan merupakan musuh peradaban karena menghambat pendidikan politik, menumpulkan inisiatif publik, dan menumbuhkan sangkaan buruk serta ketidakpercayaan rakyat terhadap pemerintah. Tanpa keterbukaan informasi, pemerintahan akan menjadi tragedi karena akan membenihkan berbagai penyimpangan.

Keterbukaan informasi publik yang dilakukan oleh Kantor Wilayah Kementerian Agama Provinsi Kalimantan Tengah menjadi salah satu elemen penting bagi terwujudnya tata kelola pemerintahan yang baik atau good governance dalam penyelenggaraan pemerintahan oleh institusi Kementerian Agama. Charlick dalam Pandji (2008) menyebutkan good governance sebagai pengelolaan segala macam urusan publik secara efektif melalui pembuatan peraturan dan/atau kebijakan yang absah demi untuk mempromosikan nilai-nilai kemasyarakatan. Dalam implementasi keterbukaan informasi publik pada Kantor Wilayah Kementerian Agama Provinsi Kalimantan Tengah, terdapat prinsip yang dapat mewujudkan good governance yaitu prinsip partisipasi, transparansi, dan akuntabilitas.

Website yang dimiliki Kantor Wilayah Kementerian Agama Provinsi Kalimantan Tengah memberikan kemudahan akses bagi masyarakat untuk mengetahui apa saja yang dilakukan instansi tersebut. Hal tersebut setidaknya diharapkan bisa menumbuhkan kepercayaan masyarakat sekaligus membangun komunikasi timbal balik. Menurut Sujatno ( Lagantondo, 20I2) transparansi adalah upaya menciptakan kepercayaan timbal balik antara pemerintah dan masyarakat melalui penyediaan informasi dan menjamin kemudahan dalam memperoleh informasi yang akurat dan memadai. Sedangkan menurut Achmadi Adib dkk (2002), tansparansi dibangun atas dasar arus informasi yang bebas. Seluruh proses pemerintahan dan informasinya harus dapat diakses oleh pihak-pihak yang berkepentingan, dan informasi yang tersedia harus memadai agar dapat dimengerti dan dipantau.

Tidak hanya itu, keterbukaan informasi publik oleh Kantor Wilayah Kementerian Agama Provinsi Kalimantan Tengah juga sebagai upaya menjaga kualitas pelayanan kepada masyarakat. Kualitas pelayanan ini, dalam pandangan Weningsih (2006) atau Sedarmayanti (1999) merupakan tujuan atau nilai penting yang harus dijaga agar dapat memenuhi harapan dan hak masyarakat sebagai pengguna layanan.

\section{Isi Kebijakan Implementasi}

Implementasi keterbukaan informasi publik pada Kantor Wilayah Kementerian Agama Provinsi Kalimantan Tengah dijalankan melalui publikasi informasi dan berita melalui website dan majalah dinas yang dimiliki. Kebijakan implementasi tersebut dijalankan menurut instruksi pimpinan lembaga melalui mekanisme internal berupa surat edaran dan nota dinas. 
Dalam pandangan Grindle (20/4), sejauh mana kepentingan kelompok sasaran dalam isi kebijakan akan berpengaruh pada partisipasi kelompok sasaran pada kebijakan implementasi keterbukaan informasi publik tersebut. Pada saat pemilik informasi pada Kantor Wilayah Kementerian Agama Provinsi Kalimantan Tengah kurang optimal dalam partisipasi implementasi keterbukaan informasi publik, hal itu bisa saja disebabkan oleh adanya perasaan bahwa kebijakan implementasi tersebut tidak terlalu berkaitan dengan kepentingan pemilik informasi pada lembaga itu.

Misal, pada saat pejabat struktural tidak optimal dalam keterbukaan informasi tersebut, hal itu akan berpengaruh pada jenjang karir atau setidaknya menjadi pertimbangan saat penentuan peletakan sebuah jabatan. Jika ini bisa dilakukan, maka kepentingan kelompok sasaran di antaranya adalah kepentingan jenjang karir jabatan akan berkaitan langsung dengan implementasi kebijakan tersebut.

Studi dokumen pada Kantor Wilayah Kementerian Agama Provinsi Kalimantan Tengah juga belum menemukan secara detil blue print arah perubahan yang diinginkan melalui keterbukaan informasi publik. Subbagian Informasi dan Humas belum memiliki pemetaan tahap implementasi tersebut sehingga ukuran perubahan yang diinginkan dari sebuah kebijakan belum dapat diketahui secara optimal. Hal tersebut kemudian berimbas pula pada letak pengambilan keputusan yang dimungkinkan belum tepat sesuai dengan arah implementasi kebijakan yang diinginkan.

Padahal, Grindle memandang faktor perubahan yang diinginkan dan ketepatan arah pengambilan keputusan sebagai bagian penting dalam isi kebijakan yang harus dipenuhi. Setidaknya diperlukan standar operasional prosedur implementasi kebijakan informasi publik yang disepakati bersama oleh seluruh unit dan satuan kerja pada lingkup Kantor Wilayah Kementerian Agama Provinsi Kalimantan Tengah. Standar tersebut kemudian menjadi panduan bagi semua pihak dalam menjalankan penerapan kebijakan keterbukaan informasi publik sesuai arah kebijakan yang telah ditetapkan Kementerian Agama pusat. Standar operasional tersebut, dalam pandangan Winarno (2005), diperlukan sebagai mekanisme pengendali internal atas kepastian waktu, sumber daya, serta penyeragaman arah dalam organisasi kerja yang luas dan kompleks.

Meski masih menghadapi sejumlah kendala, namun di sisi lain variabel isi kebijakan yaitu indikator kepentingan kelompok sasaran menunjukkan bahwa implementasi kebijakan Keterbukaan Informasi Publik pada Kantor Wilayah Kementerian Agama Provinsi Kalimantan Tengah tidak dipengaruhi oleh kepentingan pribadi atau kelompok tetapi disesuaikan dengan prosedur Undang-Undang Nomor 14 Tahun 2008 tentang Keterbukaan Informasi Publik. Kemudian pada indikator tipe manfaat menunjukkan bahwa implementasi kebijakan Keterbukaan Informasi Publik memberikan sangat bermanfaat bagi pemerintah maupun masyarakat, misalnya dalam hal penerimaan Calon Pegawai Negeri Sipil tahun 2018. Selanjutnya di indikator derajat perubahan yang diinginkan menunjukkan bahwa implementasi kebijakan keterbukaan informasi publik di Kantor Wilayah Kementerian Agama Provinsi Kalimantan Tengah telah membawa perubahan terhadap keterbukaaninformasi publik di instansi tersebut, meski masih belum sesuai dengan harapan; indikator letak pengambilan keputusan menunjukkan bahwa pengambilan keputusan dalam implementasi keterbukaan informasi publik pada Kantor Wilayah Kementerian Agama Provinsi Kalimantan Tengan masih didominasi dengan pengambilan kebijakan secara top down. Meski begitu, telah ada upaya melibatkan pihak terkait secara bottom up, dan pelibatan tersebut harus diperkuat.

Pada indikator pelaksanaan program menunjukkan bahwa proses implementasi kebijakan keterbukaan informasi publik sudah berjalan namun belum sesuai harapan. Diperlukan upaya yang lebih intensif dengan melakukan berbagai inovasi dan terobosan agar implementasi keterbukaan informasi publik menjadi 
lebih optimal dan meminimalisir adanya kendala tertentu. Hal tersebut dapat didasarkan pada masih banyaknya faktor penghambat implementasi kebijakan yang dimaksud.

Selanjutnya pada indikator sumber daya yang dilibatkan menunjukkan bahwa implementasi kebijakan keterbukaan informasi publik di Kantor Wilayah Kementerian Agama Provinsi Kalimantan Tengah telah didukung sumber daya manusia pada sisi implementatornya, namun belum didukung dengan sumber daya manusia yang memadai pada sisi partisipannya.

\section{Lingkungan Implementasi}

Dalam pandangan Grindel (20I4), seberapa besar kekuasaan, kepentingan, dan strategi yang dimiliki oleh aktor yang terlibat dalam implementasi kebijakan menjadi alat ukur penting untuk mengetahui bagaimana implementasi kebijakan tersebut berjalan. Jika aktor implementasi kebijakan pada Kantor Wilayah Kementerian Agama Provinsi Kalimantan Tengah tidak memiliki kekuasaan yang bisa mengakses semua pejabat publik - atau setidaknya diberikan kewenangan yang bisa melakukan akses tersebut - maka implementasi kebijakan keterbukaan informasi publik tidak bisa berjalan optimal. Lingkungan implementasi dari sisi kewenangan dan kekuasaan tidak mendukung secara penuh atas implementasi kebijakan yang ingin dicapai.

Alat ukur selanjutnya pada variabel lingkungan implementasi dalam pendapat Grindel (2014) adalah karakteristik institusi. Sebagai sebuah lembaga sipil, Kantor Wilayah Kementerian Agama Provinsi Kalimantan Tengah lebih mengedepankan unsur kekeluargaan dan komunikasi antarpriadi dalam penyelesaian tugas dan wewenangnya. Dengan begitu, pada saat terdapat pejabat yang belum secara optimal mendukung implementasi keterbukaan informasi publik, secara kelembagaan tidak terbiasa melakukan langkah „,represif" terhadap pejabat tersebut. Hal berbeda akan terjadi jika pada Kantor Wilayah Kementerian Agama Provinsi Kalimantan Tengah memiliki karakteristik yang lebih „tegas dan keras" saat terjadi hal-hal yang tidak sesuai dengan kebijakan lembaga.

Dari hasil penelitian pada variabel lingkungan implementasimenunjukkan hasil bahwa pada indikator kekuasaan, kepentingan danstrategi aktor yang terlibat memperlihatkan tentang bagaimana implementasi kebijakan keterbukaan informasi publik di Kantor Wilayah Kementerian Agama Provinsi Kalimantan Tengah yang belum didukung dengan fungsi kontrol dan mekanisme pengendalian internal sebagaimana mestinya dari pimpinan lembaga. Sementara berdasarkan indikator karakteristik lembaga dan penguasa serta indikator kepatuhan dan daya tanggap menunjukkan keberhasilan implementasi yang ada saat ini bisa ditingkatkan karena karakteristik lembaga mendukung pelaksanaan implementasi tersebut, tinggal bagaimana meningkatkankepatuhan unsur pejabat publik di dalamnya saja.

Dalam semua ruang lingkupnya, 2 (dua) poin pokok untuk mengetahui implementasi kebijakan keterbukaan informasi publik pada Kantor Wilayah Kementerian Agama Provinsi Kalimantan Tengah menunjukkan bahwa ada beberapa sub poin yang menunjukkan adanya potensi penyebab kurang efektifnya implementasi kebijakan tersebut. Dalam sudut pandang yang lebih luas, potensi kendala itu bisa diantisipasi melalui berbagai hal. Salah satunya adalah mengintensifkan komunikasi di dalam perangkat organisasi yang dimiliki oleh Kantor Wilayah Kementerian Agama Provinsi Kalimantan Tengah.

\section{KESIMPULAN}

Implementasi keterbukaan informasi publik pada Kantor Wilayah Kementerian Agama Provinsi Kalimantan Tengah telah dijalankan denganmempublikasikan informasi melalui media internal meliputi website,majalah dinas, dan media sosial yang dikelola instansi tersebut. Dalam implementasi keterbukaan informasi publik, Kantor Wilayah Kementerian Agama 
Provinsi Kalimantan Tengah menemui sejumlah kendala, yakni :

a. Adanya keengganan dari sejumlah pejabat publik serta perbedaan kepatuhan dan responsivitas pejabat publik untuk menyerahkan beberapa informasi publik yang bersifat sensitif dan cenderung menyangkut hal pribadi, adanya pandangan bahwa tidak semua masyarakat memerlukan informasi tersebut, serta belum didukung dengan reward and punishment yang jelas.

b. Sejumlah pejabat publik merasa belum mendapatkan manfaat langsung dari dipublikasikannya informasi kepada masyarakat, terutama informasi-informasi yang bersifat personal.

c. Masih belum tersedianya road map arah perubahan keterbukaan informasi publik dan pedoman teknis implementasinya sebagai acuan bagi implementator dan pihak yang terkait.

d. Belum optimalnya mekanisme perencanaan implementasi kebijakan secara bottom up.

e. Belum meratanya kualitas sumber daya manusia pada sisi implementator maupun kelompok target sasaran.

f. Keterbatasan wewenang, kekuasaan, dan strategi yang diambil dalam implementasi kebijakan keterbukaan informasi publik.

\section{REFERENSI}

Akib, Haedar, \& Tarigan, Antonius, 2008. “Artikulasi Konsep Implementasi Kebijakan: Perspektif, Model dan Kriteria Pengukurannya," Jurnal Baca, Volume I Agustus 2008, Universitas Pepabari Makassar.

Febriananingsih, Nunuk. 2012. "Keterbukaan Informasi Publik Dalam Pemerintahan Terbuka Menuju Tata Pemerintahan Yang Baik,” dalam Jurnal RechtsVinding, Volume I Nomor I.
Hardyanti, Winda. 2015. "Konsep Best Practices Implementasi UU Keterbukaan Informasi Publik No 14/2008." dalam Jurnal Wacana, Volume XIV No. 4.

Indah, Tiara \& Hariyanti, Puji. 2018. "Implementasi Kebijakan Keterbukaan Informasi Publik pada Dinas Kominfo Kota Tasikmalaya," dalam Jurnal Komunikasi, Volume 12, Nomor 2.

Komisi Informasi Republik Indonesia, 2010. Peraturan Komisi Informasi Republik Indonesia Nomor I Tahun 2010 tentang Standar Layanan Informasi. Jakarta: Komisi Informasi Republik Indonesia.

Kopfman, Jenifer E., \& Ruth-McSwain, Amanda. 2012. Public Information Campaigns hal. 75 - 99 dalam Mordecai Lee, Grant Neeley, \& Kendra Stewart (edt), The Practice of Government Public Relations. Florida: CRC Press.

Prabowo, Rizki Dwi. 2016. “Implementasi UndangUndang Keterbukaan Informasi Publik dalam Upaya Mewujudkan Good Governance (Kajian Tiga Badan Publik: Bappeda, DPKAD dan Dinas Pendidikan Kota Semarang)" dalam Jurnal Diponegoro, Vol. 8.

Sastro, Dhoho A., Yasin, M., Gunawan, Ricky, Julitasari, Rosmi \& Bawor, Tandiono. 2010. Mengenal Undang-Undang Keterbukaan Informasi Publik. Jakarta: Yayasan Tifa.

Teoh, Siew Hong. 2014. "Information disclosure and voluntary contributions to public goods." dalam The RAND Journal of Economics, Vol. 28, No. 3.

Wood, Jack., Wallace, Joseph., \& Zeffane, Rachid M. 2001. Organisational Behaviour: A Global Perspective. Quensland: John Wiley \& Sons Australia, Ltd.

Yin, Robert K. 2003. Case Study Research Design and Methods. California: Sage Publications, Inc. 